\title{
REPORTS OF THE USE OF URTICACEAE COLLECTED IN BRAZIL AND DEPOSITED IN THE HERBARIA OF KEW (K), NEW YORK (NY) AND PARIS (P)
}

\author{
Amanda Roberta Corrado*, André Luiz Gaglioti', Sergio Romaniuc Neto², and Lin Chau Ming
}

Guest editors: Maria F.T. Medeiros and Alain Touwaide

\begin{abstract}
The purpose of this study was to use a historical series of exsiccates as a documentary source, aiming to retrieving information on species of Urticaceae Juss. The study approached the collections of exsiccates belonging to herbaria of the Royal Botanic Gardens (K), Kew, England; Muséum National d'Histoire Naturelle (P), Paris, France; and New York Botanical Garden (NY), New York, USA, also printed sources and manuscripts. We analyzed more than 2800 exsiccates, comprising the period between 1783 and 2003. From the information labels of the exsiccates, it was possible to obtain the use and common name of the Urticaceae species. A total of thirteen species with register of use were find in the labels, six genera of Urticaceae: five species of Pourouma Aubl., three of Cecropia Loefl., two of Urera Gaudich., one of Boehmeria Jacq., one of Coussapoa Aubl., one of Laportea Gaudich. Five categories of usage were identify: (1) animal feeding; (2) human feeding; (3) medicinal; (4) fiber and (5) fuel. The analysis of the labels registers pointed to be efficient to raise information related to Urticaceae species, and combined to the research of printed sources and manuscripts provide more details to the data. Furthermore, adding information to the review of the collections history in Brazil. It is necessary to establish initiatives which facilitate the access to documents associated to exsiccates, like the manuscripts of collectors, for continuing the advances in the retrieval of knowledge registered.
\end{abstract}

Keywords: Historical ethnobotany, Exsiccates, Historical collections, Useful plants.

\section{INTRODUCTION}

The people knowledge about natural living environment integrates a complex and dynamic system. The diachronic analysis of the complexity and dynamics of the plants use by population can bring answers about the adaptive nature of this type of knowledge, as well as about the various social factors that affect them unevenly, which is generated, transmitted or lost according to the specific needs of a society at a determinate given point of time (Reyes-García et al. 2013).

Contemporary, historical documents allow the access of data on the different uses of plants in the past periods, evaluating different collections, such as the manuscripts of Persian traditional medicine (Ameri et al. 2015; Hamedi 2013); records and graphics of European Herbals (Adams et al. 2012, Adams et al. 2011; Vos 2010; Buenz et al. 2004); floras pre-Linnaean (Spalik 2014), the herbarium

1 Programa de Pós-Graduação em Agronômia/Horticultura, Departamento de Horticultura, Faculdade de Ciências Agronômicas, Universidade Estadual Paulista, Botucatu, SP, 18610-307, Brazil

* Corresponding author. E-mail adresses: ARC (amandacorrado@gmail.com), LCM (linming@fca.unesp.br)

2 Instituto de Botânica, Herbarium SP, Av. Miguel Stéfano, 3687, 04301-902, São Paulo, SP, Brazil 
(Andel et al. 2012a; Andel et al. 2012b) and forgotten ethnobotanical collections (Luczaj et al. 2013; Natale and Pollio 2012; Sandberg et al. 2005).

The scientific evaluation of these documents has allowed the retrieval of knowledge on the use of neglected plants and the conservation evaluation of native species, which still need studies for potential use (Medeiros and Albuquerque 2014; Breitbach et al. 2013; Giorgetti et al. 2011). Other contributions to scientific assessment of historical documents was the analysis of the transmission of knowledge about plants over time (Cero et al. 2014; Luczaj et al. 2013, Cosenza et al. 2013; Leonti 2011; Luczaj 2010; Kufer et al. 2005).

In the Americas, the written records date back to the beginning of colonization with the documents produced by explorers in the new lands. The Brazil flora was first described in the letter of Pero Vaz de Caminha to King Dom Manoel (Filgueiras and Peixoto 2002). However, more systematic documentation of information on natural resources was produced between the 17th and 19th centuries, when the Enlightenment criteria were incorporated in the natural sciences. This period is characterized, from a scientific point of view, by the movement of naturalist travelers in the colonies land (Leite 1995; Vos 2007) and collections send out to compose the collections of natural history museums abroad (Lopes and Heizer 2011; Kury 2001).

Behind the pursuit of new knowledge in natural sciences, there was an ideology that dominated the scientific trips, where nature was the focus for human development (Kury 2001; Vos 2007). This perspective scientific voyages is reinforced when we look at the "Travel Instructions", produced by natural history museums to guide the studies and records of traveler naturalists. Aspects such as natural and industrial products to be collected and how they should be prepared, places to collect, ethnographic observations that should be made, production of travel diaries and the record of knowledge of native plants, approached the theoretical and practical tools trip (Pataca 2011; Kury 1998).

One exsiccate is the basic unit of botanical collections, is a mixed document containing records in written form (label) that allow to obtain a copy of the information in its natural formation, which are usually lost when the sample is dehydrated, (Smith et al. 2012) and harvest plant sample. This material is often used by taxonomy researchers, who uses the fixed plant and the records contained on the label for their studies. However, other data recorded on the labels can be analyzed in the study of the stages of botany evolution, history collectors, ethnobotanical data and changes generated by human actions over time in the landscape (Peixoto 2005).

Given the characteristics of the documents produced by naturalists, recent work has focused on this material for historical ethnobotanical studies, such as manuscripts and field diaries (Fagg et al 2015; Brandão et al. 2012; Giorgetti, et al. 2011; Brandão et al. 2008), historical botanical collections (Andel et al. 2012b; Guerra et al. 2011), historical collections, along with the collectors of manuscripts (Moraes et al. 2014) and the common name records (Andel et al. 2014).

Urticaceae is commonly known as the nettle family, which comprises about 55 genera and more than 2000 species (Gaglioti and RomaniucNeto 2014). It is distributed throughout tropical and temperate regions worldwide, but its center of diversity is indicated for the tropics, with largest concentration of species in Asia (Wu et al. 2013). The family includes herbs, hemi-epiphytes, shrubs, or trees, and its synapomorphies are: latex restrict to the bark, cystoliths or silicon-accumulation in the leaves, pseudomonomerous ovary with one style, basal orthotropous ovule, achene fruits (Gaglioti and Romaniuc-Neto 2014).

This study focuses on the reading and analysis of labels of a time series composed by the exsiccates from the Urticaceae, to survey data on: (1) past use of species of this family; (2) vernacular names, information that could lead to the use of the plant.

\section{MATERIAL AND METHODS}

\section{Characterization of the collections analyzed}

The series of exsiccates ${ }^{3}$ of this study belong to herbaria of the Royal Botanic Gardens (K), Kew,

3 Exsiccata: used the word towards, a set of dried specimens usually provided with printed labels. Botanical Latin 1992, 14 ed. Willian T. Stearn. 
England; the Muséum National d'Histoire Naturelle (P), Paris, France; and the New York Botanical Garden (NY), New York, U.S.A. In the collection of the herbaria that belong to the project REFLORA, $\mathrm{K}$ and $\mathrm{P}$, around 80 per cent of the nomenclatural types are clade Urticoide. Deposited in the last, we have collection of Hugh Algernon Weddell, Auguste François Marie Glaziou, and Auguste François César Prouvençal de Saint-Hilaire, naturalists that have been in Brazil and have dedicated their time to the study of the classification of families of the clade Urticoide.

The presence of such exsiccates indicated that this collection presents significate number of exsiccates collected in the beginning of 19th century. The NY collection is characterized by a more recent collection, composed mainly from the second half of the 20th century, when collaboration started between the NY herbarium and Brazilian institutions.

\section{Digital Photographic Filing}

The photographs of the series of exsiccates of the family Urticaceae belonging to the $\mathrm{P}$ herbarium have been taken in 2010, the ones from $K$ in August 2013 and the ones from NY in January 2011. The exsiccates were photographed with digital camera, 14 mega pixels resolution and stored in JPEG format (Joint Photographic Experts Group), a format that allows good image compacting.

The images of exsiccates series of herbaria were kept in individual files named by the acronym corresponding of herbarium. In the file of herbaria, the images were subdivided into folders with the names of the Urticaceae family genus. The images were placed in folders according to the corresponding gender to be identified on the label.

After subdivision, the images were given a default name to the country belonging numeral. For Brazil, we use the number 1, followed by the museum's acronym, the species gender and sequential numbering to individualization. As an example, images of the photographic file belonging to herbarium of Paris, of the genus Pilea folder, were named as follows: 1_P_Pilea_1; 1_P_Pilea_2; and so on until 1_P_Pilea_89. The images of photographic file belonging to herbarium at $K$, of the genus Pilea folder, were named as follows: 1_K_Pilea_1; 1_K_ Pilea_2; and so on until 1_K_Pilea_ 52.

\section{Reading and interpretation of the label registers}

Labels of exsiccates, mainly historical, were at the time of their collection, handwritten having such cases reading difficulties due to handwriting. For these cases, the records passed by a data interpretation process where this hand writing on the label was compared to the botanical the time for data entry in the database, to follow the way of record labels, mostly common names and locations.

For historical exsiccates without the collector name registration, calligraphy labels were designed to reach the calligraphy author's name, with the calligraphy of the study came to the name of a botanical and collections dates matched the date of travel collector to Brazil, it was assumed that the exsiccates had been collected by botanist identified by calligraphy.

For the study and interpretation of the botanical calligraphy we used the online catalogs of four botanical institutions of calligraphy: of the Coimbra Herbarium, Conservatory and Botanic Garden of the city of Geneva, Global Plants Initiative (GPI) and of the Royal Botanic Garden of Madrid. These catalogues include samples of writing in different languages, herbarium labels and fragments of letters and other documents showing the different forms of calligraphy of each selected botanic. Besides these samples, they provide essential bibliographic reference for the most comprehensive review of the literature published about the botanic in question.

\section{Systematization of the labels information}

The data labels were organized in a database, in the software FileMaker Pro 13.0v3, all of the data entered as their record labels. For data interpreted in the case of historical exsiccates, the words were marked red for the interpreted data of distinction and data entered as they appear on the label to ensure greater accuracy at the time of data analysis. 
To update the scientific names, we referred to the databases of The International Plant Names Index - IPNI, Tropicos.org of Missouri Botanical Gardens, List of the Flora of Brazil of Rio de Janeiro Botanic Garden, specialized literature and review of specialists on the Urticaceae, from Instituto de Botânica de São Paulo (IBt).

The information obtained with the systematization of information of the labels, traveler's books, field journals, bibliographic material, and mail about travels in Brazil, and different works produced by the collectors were consulted. The consultations were made in the Library of the Herbarium of Kew and Paris, private library of Dr. Lin Chau Ming, Central Library and Library of the Institute of Philosophy and Social Science at UNICAMP, online data bases and rare books: Internet Archival, JSTOR Global Plants Biodiversity Heritage Library, Herbarium Virtual A. of Saint-Hilaire, Flora Brasiliensis, Library Curt Nimuendaju and Open Library.

\section{RESULTS AND DISCUSSION}

Six genera of Urticaceae present registers of use in the labels: five species of Pourouma, three of Cecropia, two of Urera, one of Boehmeria, one of Coussapoa, and one of Laportea. A total of thirteen species with register of use displayed in figure 1, 2, 3 and 4 and thirty-five registers have been found. For the common name were raised thirty records some in Portuguese and other languages in the Makú, Kaapor and Yanomami ethnic groups. All data are presented in table 1.
The uses were categorized in: 1) animal feeding; (2) human feeding (3) medicinal; (4) fiber; and (5) fuel. In the category human feeding there are 22 registers, distributed in seven species, Cecropia concolor Willd., Coussapoa microcarpa (Schott) Rizzini, Pourouma bicolor Mart., P. cecropiifolia Mart., P. cucura Standl. \& Cuatrec, P. guianensis Aubl., P. minor Benoist., 20 being of Pourouma. The edible fruits of Pourouma have been related for a long time.

Richard Spruce describes Pourouma as one of the favorite fruits in Equatorial America and considers de genus similar to Cecropia, for the similarity of shape, leaves and colors. He reports to find distinction between the species founding the region in middle River Negro and the margins of the rivers Jupurá and Solimões. Spruce's account, on the distinction made by the indigenous peoples, who name with three different adjectives and on the derivation of primitive species is correlated to the contemporary data, which show the existence in all Amazonia of Pourouma cecropiifolia Mart, non-domesticated, wild, with small fruits and the ethnic groups Tikuna (River Solimões), Tukano (River Negro) and others under their influence have been selected this species, with great efficiency, keeping varieties which considerably distinguish from the primitive species (Kerr and Clement 1980).

Ten exsiccates were categorized in the category medicinal, belonging six species: Cecropia obtusa Trécul, C. pachystachya Trécul, Laportea aestuans (L.) Chew, Urera baccifera (L.) Gaudich. ex Wedd., and Urera caracasana (Jacq.) Gaudich. ex Griseb. The medicinal uses are generally for antiinflammatory, and diabetes. 


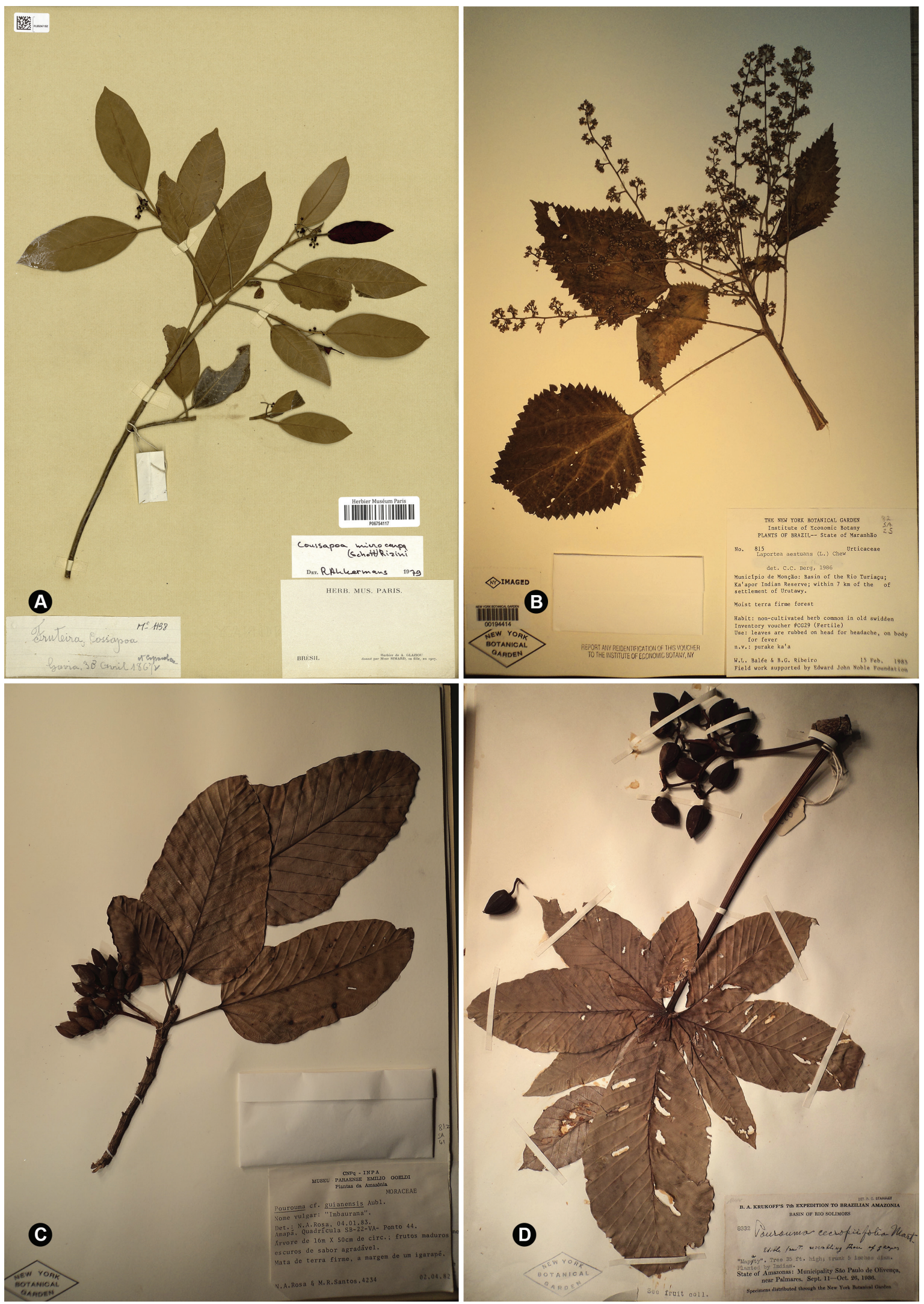

Figure 1. A - Coussapoa microcarpa (Glaziou, A.F.M. 1138, P). B - Laportea aestuans (Balée, W.L. et al. 815, NY). C - Pourouma bicolor (Rosa, N.A. et al. 4234, NY). D - Pourouma cecropiifolia (Krukoff, B.A. 8332, NY) 


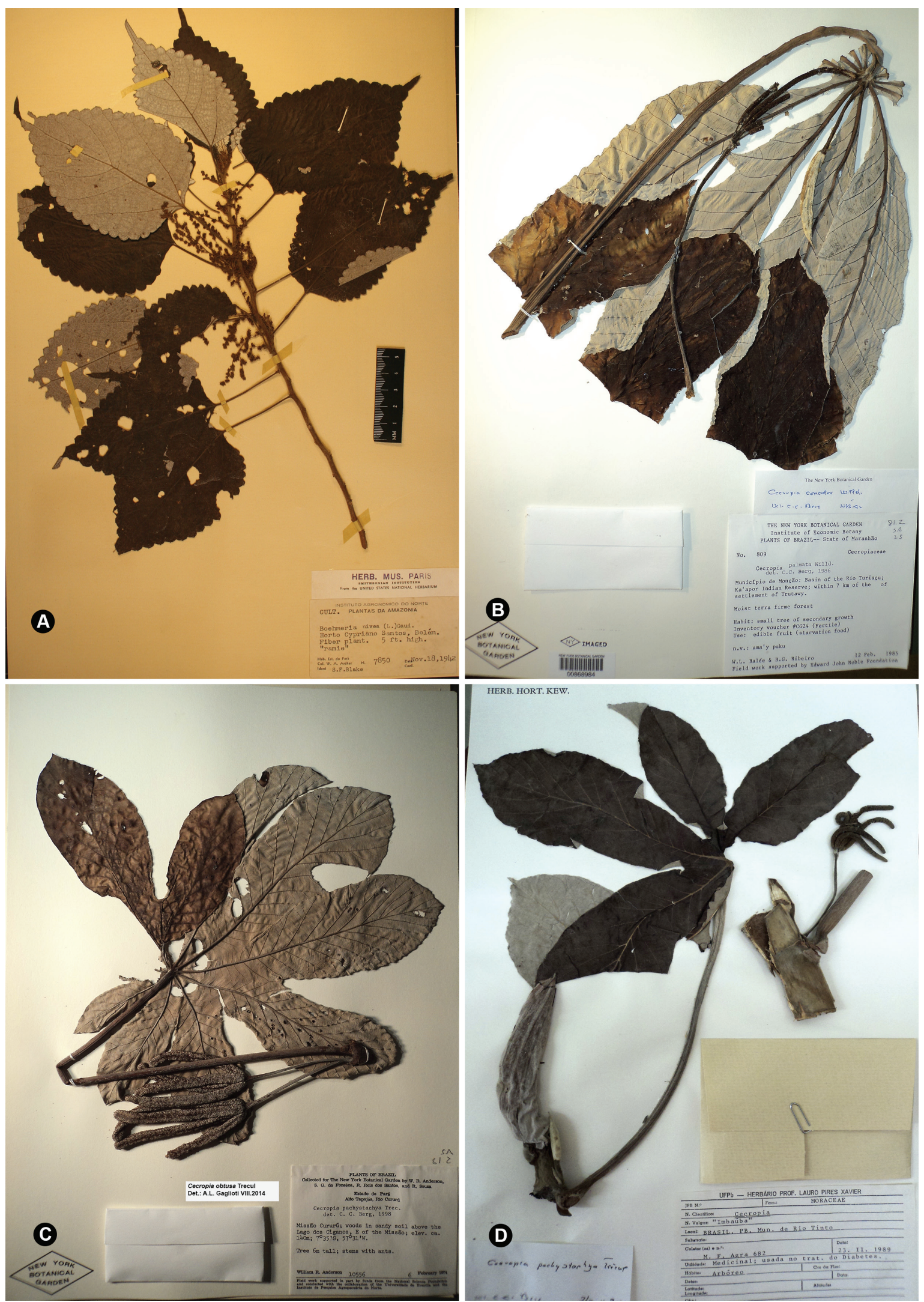

Figure 2. A - Boehmeria nivea (Archer, W.A. 7850, P). B - Cecropia concolor (Balée, W.L. 809, NY). C - Cecropia obtusa (Anderson, W.R. 1056, NY). D - Cecropia pachystachya (Agra, M.F. 682, K). 

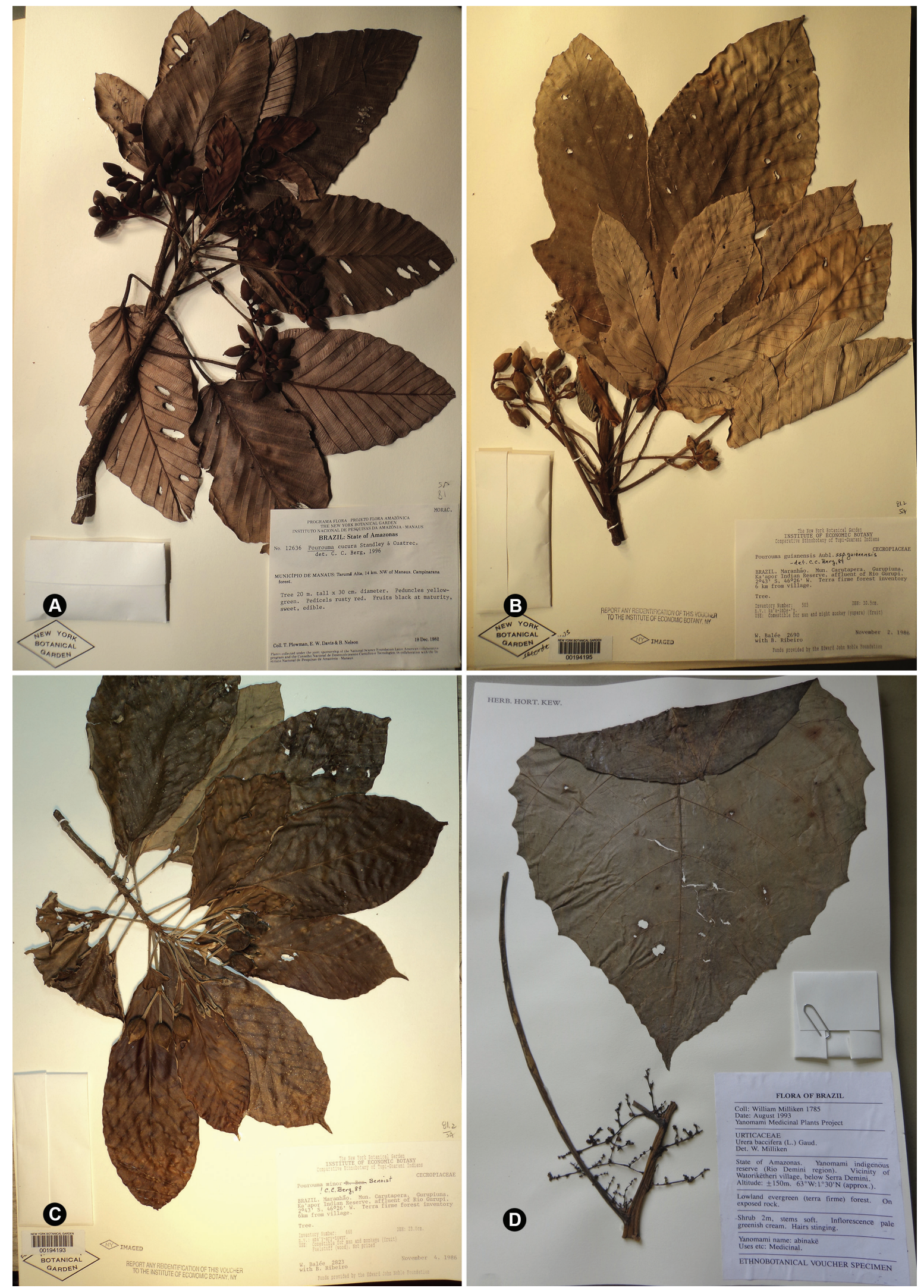

Figure 3. A - Pourouma cucura (Plowman, T. et al. 12636, NY). B - Pourouma guianensis (Balée, W.L. et al. 2690, NY). C - Pourouma minor (Balée, W.L. et al. 2823, NY). D - Urera baccifera (Milliken, W. 1785, K). 


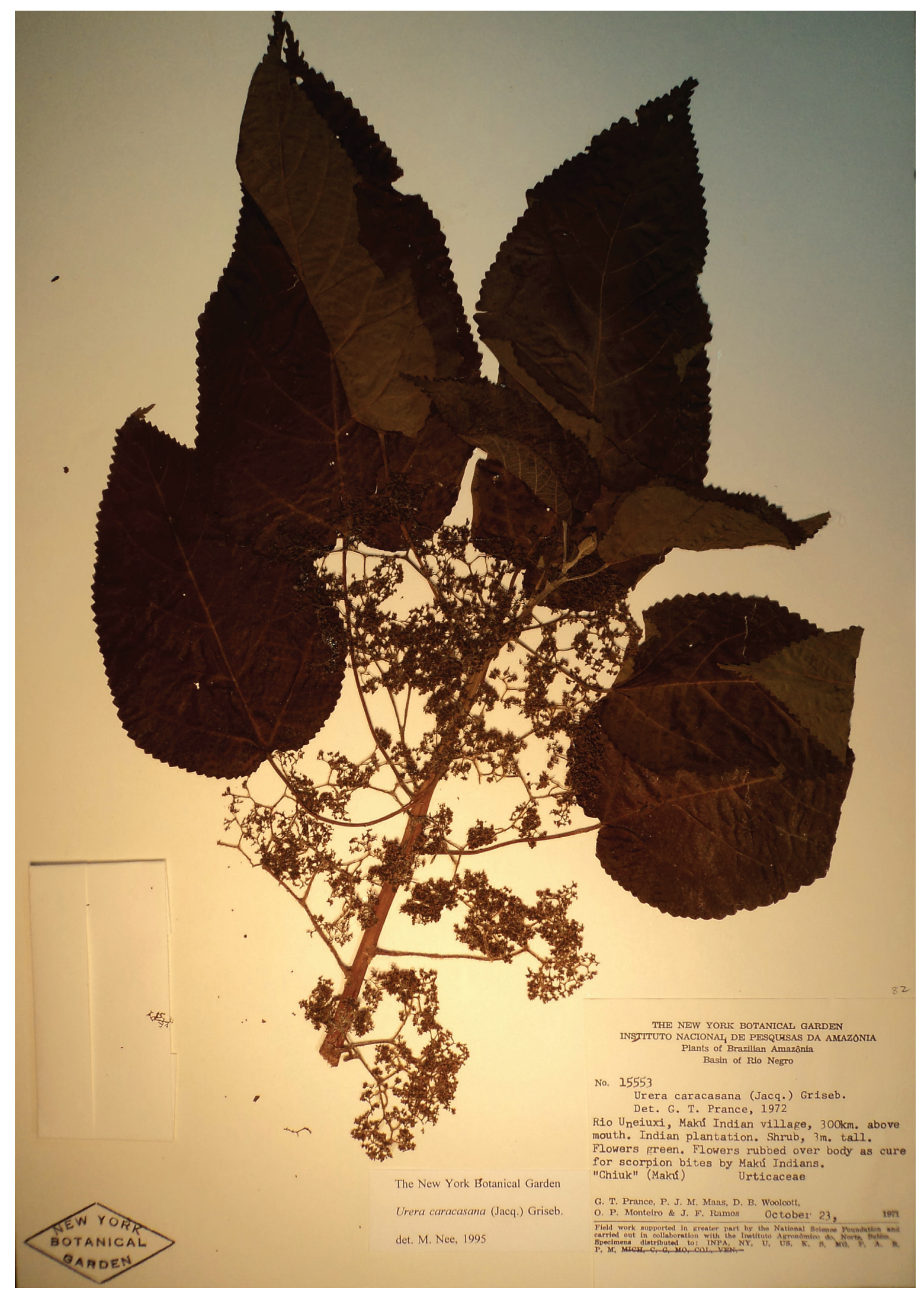

Figure 4. Urera baccifera (Prance, G.T. et al. 1553, NY). 
Table 1. Register of use of Urticaceae in the labels of the botanic collections of Royal Botanic Gardens (K), Muséum National d'Histoire Naturelle (P); and New York Botanical Garden (NY).

\begin{tabular}{|c|c|c|c|c|c|c|c|}
\hline Scientific name & Use in the Label & $\begin{array}{c}\text { Common Name } \\
\text { Register }\end{array}$ & Collector & $\begin{array}{l}\text { Number of } \\
\text { Collector }\end{array}$ & $\begin{array}{l}\text { State of } \\
\text { the Brazil }\end{array}$ & $\begin{array}{l}\text { Colletion } \\
\text { Year }\end{array}$ & Herbarium \\
\hline Boehmeria nivea & Fiber & rami & Archer, W.A. & 7850 & Pará & 1942 & $N Y, P$ \\
\hline Cecropia concolor & Human feeding & $\begin{array}{l}\text { ama'y puku } \\
\text { (Kaapor)* }\end{array}$ & Balée, W.L. & 809 & Maranhão & 1985 & NY, K \\
\hline Cecropia obtusa & $\begin{array}{l}\text { Medicinal and } \\
\text { animal feeding }\end{array}$ & Imbauba & $\begin{array}{l}\text { Anderson, } \\
\text { W.R. }\end{array}$ & 1056 & Pará & 1984 & NY, K \\
\hline $\begin{array}{l}\text { Cecropia } \\
\text { pachystachya }\end{array}$ & Medicinal & Imbauba & Agra, M.F. & 682 & Paraíba & 1989 & $\mathrm{~K}$ \\
\hline $\begin{array}{l}\text { Coussapoa } \\
\text { microcarpa }\end{array}$ & Human feeding & & Glaziou, A.F.M. & 1138 & $\begin{array}{l}\text { Rio de } \\
\text { Janeiro }\end{array}$ & 1867 & $P$ \\
\hline \multirow[t]{4}{*}{ Laportea aestuans } & Medicinal & $\begin{array}{l}\text { poraka ka' a } \\
\text { (Kaapor)* }\end{array}$ & Balée, W.L. & 815 & Maranhão & 1985 & $\mathrm{NY}, \mathrm{K}$ \\
\hline & Animal feeding & pinu-pinu & Balée, W.L. & 2625 & Pará & 1986 & NY \\
\hline & Medicinal & urtiga & Bruce, N & 783 & Acre & 1980 & NY \\
\hline & Medicinal & urtiga vermelha & Daly, D.C. & 9914 & Acre & 1999 & NY \\
\hline \multirow[t]{2}{*}{ Pourouma bicolor } & $\begin{array}{l}\text { Human feeding } \\
\text { and fuel }\end{array}$ & $\begin{array}{l}\text { ama'yw-ci } \\
\text { (Kaapor)* }\end{array}$ & $\begin{array}{l}\text { Balée, W.L. } \\
\text { et al. }\end{array}$ & 1344 & Pará & 1985 & NY \\
\hline & Human feeding & imbaurana & $\begin{array}{l}\text { Rosa, N.A. } \\
\text { et al. }\end{array}$ & 4234 & Amapá & 1982 & NY \\
\hline \multirow[t]{5}{*}{$\begin{array}{l}\text { Pourouma } \\
\text { cecropiifolia }\end{array}$} & Human feeding & & $\begin{array}{l}\text { Alexiades, } \\
\text { M.N. et al. }\end{array}$ & 1110 & Amazonas & 1991 & NY \\
\hline & Human feeding & mapaty & Krukoff, B.A. & 8332 & Amazonas & 1936 & NY \\
\hline & Human feeding & & $\begin{array}{l}\text { Mori, S.A. } \\
\text { et al. }\end{array}$ & 10409 & Bahia & 1978 & NY \\
\hline & Human feeding & & $\begin{array}{l}\text { Prance, G.T. } \\
\text { et al. }\end{array}$ & 15791 & Amazonas & 1971 & NY \\
\hline & Human feeding & mapati & Silveira, M. & 867 & Acre & 1994 & NY \\
\hline Pourouma cucura & Human feeding & & Plowman, $\mathrm{T}$. & 12636 & Amazonas & 1982 & NY \\
\hline \multirow[t]{7}{*}{$\begin{array}{l}\text { Pourouma } \\
\text { guianensis }\end{array}$} & Human feeding & $\begin{array}{l}\text { kaymbe 'y } \\
\text { (Kaapor)* }\end{array}$ & Balée, W.L. & 968 & Maranhão & 1985 & NY \\
\hline & $\begin{array}{l}\text { Human and } \\
\text { animal feeding }\end{array}$ & $\begin{array}{l}\text { ka'a-bem-ý } \\
\text { (Kaapor)* }\end{array}$ & $\begin{array}{l}\text { Balée, W.L. } \\
\text { et al. }\end{array}$ & 2688 & Maranhão & 1986 & NY \\
\hline & $\begin{array}{l}\text { Human and } \\
\text { animal feeding }\end{array}$ & $\begin{array}{l}\text { ka'a-bem-ý } \\
\text { (Kaapor)* }\end{array}$ & $\begin{array}{l}\text { Balée, W.L. } \\
\text { et al. }\end{array}$ & 2690 & Maranhão & 1986 & NY \\
\hline & $\begin{array}{l}\text { Human and } \\
\text { animal feeding }\end{array}$ & $\begin{array}{l}\text { ka'a-imb-'y } \\
\text { (Kaapor)** }\end{array}$ & $\begin{array}{l}\text { Balée, W.L. } \\
\text { et al. }\end{array}$ & 2759 & Maranhão & 1986 & NY \\
\hline & $\begin{array}{l}\text { Human and } \\
\text { animal feeding }\end{array}$ & $\begin{array}{l}\text { ka'a-imbe-'y } \\
\text { (Kaapor)* }\end{array}$ & $\begin{array}{l}\text { Balée, W.L. } \\
\text { et al. }\end{array}$ & 2763 & Maranhão & 1986 & NY \\
\hline & $\begin{array}{l}\text { Human and } \\
\text { animal feeding }\end{array}$ & $\begin{array}{l}\text { Ka'a-bem-'y } \\
\text { (Kaapor)* }\end{array}$ & $\begin{array}{l}\text { Balée, W.L. } \\
\text { et al. }\end{array}$ & 2903 & Maranhão & 1986 & NY \\
\hline & $\begin{array}{l}\text { Animal feeding; } \\
\text { fuel }\end{array}$ & $\begin{array}{l}\text { ama-'y-ca'ã-'y } \\
\text { (Kaapor)* }\end{array}$ & Balée, W.L. & 3211 & Maranhão & 1987 & NY \\
\hline \multirow[t]{2}{*}{ Pourouma minor } & $\begin{array}{l}\text { Human and } \\
\text { animal feeding }\end{array}$ & $\begin{array}{l}\text { ama'y-rary-tuwyr } \\
\text { (Kaapor)* }\end{array}$ & $\begin{array}{l}\text { Balée, W.L. } \\
\text { et al. }\end{array}$ & 2693 & Maranhão & 1986 & NY \\
\hline & $\begin{array}{l}\text { Human and } \\
\text { animal feeding }\end{array}$ & $\begin{array}{l}\text { ama'y-rary-tuwyr } \\
\text { (Kaapor)* }\end{array}$ & $\begin{array}{l}\text { Balée, W.L. } \\
\text { et al. }\end{array}$ & 2710 & Maranhão & 1986 & NY \\
\hline
\end{tabular}




\begin{tabular}{|c|c|c|c|c|c|c|c|}
\hline Scientific name & Use in the Label & $\begin{array}{c}\text { Common Name } \\
\text { Register }\end{array}$ & Collector & $\begin{array}{l}\text { Number of } \\
\text { Collector }\end{array}$ & $\begin{array}{l}\text { State of } \\
\text { the Brazil }\end{array}$ & $\begin{array}{l}\text { Colletion } \\
\text { Year }\end{array}$ & Herbarium \\
\hline & $\begin{array}{l}\text { Human and } \\
\text { animal feeding }\end{array}$ & $\begin{array}{l}\text { ama'y-rary-tuwyr } \\
\text { (Kaapor)* }\end{array}$ & $\begin{array}{l}\text { Balée, W.L. } \\
\text { et al. }\end{array}$ & 2747 & Maranhão & 1986 & NY \\
\hline & $\begin{array}{l}\text { Human and } \\
\text { animal feeding; } \\
\text { fuel }\end{array}$ & $\begin{array}{l}\text { ama'y-rary-tuwyr } \\
\text { (Kaapor)* }\end{array}$ & $\begin{array}{l}\text { Balée, W.L. } \\
\text { et al. }\end{array}$ & 2803 & Maranhão & 1986 & NY \\
\hline & $\begin{array}{l}\text { Human and } \\
\text { animal feeding; } \\
\text { fuel }\end{array}$ & $\begin{array}{l}\text { ama'y-rary-tuwyr } \\
\text { (Kaapor)* }\end{array}$ & $\begin{array}{l}\text { Balée, W.L. } \\
\text { et al. }\end{array}$ & 2804 & Maranhão & 1986 & NY \\
\hline & $\begin{array}{l}\text { Human and } \\
\text { animal feeding }\end{array}$ & $\begin{array}{l}\text { ama'y-rary-tuwyr } \\
\text { (Kaapor)* }\end{array}$ & $\begin{array}{l}\text { Balée, W.L. } \\
\text { et al. }\end{array}$ & 2823 & Maranhão & 1986 & NY \\
\hline \multirow[t]{2}{*}{ Urera baccifera } & Medicinal & $\begin{array}{l}\text { Abinake } \\
\text { (Yanomami)* }^{*}\end{array}$ & Milliken, W. & 1785 & Amazonas & 1993 & NY, K \\
\hline & Medicinal & $\begin{array}{l}\text { Abinasik } \\
\text { (Yanomami)* }^{*}\end{array}$ & Prance, G.T. & 23604 & Amazonas & 1975 & NY \\
\hline \multirow[t]{3}{*}{ Urera caracasana } & Medicinal & puni-puiní & Glaziou, A.F.M. & 10058 & $\begin{array}{l}\text { Espírito } \\
\text { Santo }\end{array}$ & 1890 & $P$ \\
\hline & Medicinal & Ishanga & Prance, G.T. & 6337 & Pará & 1970 & NY \\
\hline & Medicinal & Chiuk (Makú) & Prance, G.T. & 15553 & Amazonas & 1971 & NY \\
\hline
\end{tabular}

* indigenous ethnic groups

Peckolt and Peckolt (1888), and Le Cointe (1945) related the medicinal use of the most species studied here, with the exception of Cecropia obtusa, and Laportea aestuans

Giorgetti (2011) remarked about the pontential medicinal of Cecropia peltata L. Moreover, the author cited the lack pharmacology studies for this species.

Some genera (e.g, Laportea, Urera) display medicinal potencial as anti-inflammatory, antimicrobial, antiulcer, antidiabetic and anesthetic (Gaglioti and Romaniuc-Neto, 2014). Moreover, the family has economically important species for the fabrication of fibers and ornamental usage, such as: rami, Boehmeria nivea (Duan et al. 2012).

The indication for use of fiber found in the labels refers to an exotic species, Boehmeria nivea (L.) Gaudich. The use of the species Cecropia and Urera is known and reported in the printed sources (Saint-Hilaire 2011; Sorarú 1972; Peckolt and Peckolt 1888). Saint-Hilaire (1975) reported in details the production of fiber species of the genus Cecropia from young branches by women of the ethnic group Macuni, who produce a cord used to make bags, nets and bows.
In the fuel category were grouped species with logging of wood for charcoal making, and for the production of gunpowder from the ashes. The ashes of wood were also recorded as for soap manufacturing, whitening clothes and sugarcane juice.

The multiplicity of uses recorded on labels and in historical literature reveal the richness and diversity of knowledge of local people about the species of the Urticaceae. Through the records and annotation labels of herbarium specimens, and the historical literature, we found the knowledge of resources in some moments of time an indication of the potential use of these species for future work.

\section{CONCLUSIONS}

The analysis of the labels registers has shown to be efficient to raise information on use and common names of the Urticaceae species, which integrated to printed sources and manuscripts, have provided more details of the data, and contributed for the review of the history of collections in Brazil. 
The series of the studied collections follows a period from 1783 to 2003 , and at different times were recorded uses of species of the Urticaceae. The survey of these reports back to the contemporary potential of genetic resources of this family as the food and feed supply, medical, fiber and energy production, which in the past were used by people.

For the advance in the retrieval of knowledge registered in the labels to continue, it is necessary to establish initiatives which make available material associated to the exsiccates and easy access, such as collector's manuscripts.

\section{ACKNOWLEDGEMENTS}

We would like to thanks Maria Franco Trindade Medeiros (Centro de Educação e Saúde, Universidade Federal de Campina Grande,) for her critical review of the methodology. Funding for this work has been provided by Project "Resgate Histórico e Herbário Virtual para o Conhecimento e Conservação da Flora Brasileira" - REFLORA, CNPq (proc. 563551/2010-0) / FAPESP (proc. 2010/52.487-2).

\section{REFERENCES}

1. Adams M, Alther W, Kessler M, Kluge M, Hamburger M (2011) Malaria in the Renaissance: Remedies from European Herbals from the 16th and 17th Century. Journal of Ethnopharmacology 133(2):278-88.

2. Adams M, Alther W, Kessler M, Kluge M, Hamburger M (2012) Epilepsy in the Renaissance: A Survey of Remedies from 16th and 17th Century German Herbals. Journal of Ethnopharmacology 143(1):1-13.

3. Ameri A, Heydarirad G, Mahdavi JJ, Ghobadi A, Rezaeizadeh H, Choopani R (2015) Medicinal Plants Contain Mucilage Used in Traditional Persian Medicine (TPM). Pharmaceutical Biology 53(4):615-623

4. Andel T, 't Kloosterc CIEA, Quiroza D, Townsa AM, Ruysschaerte S, Bergf M (2014) Local Plant Names Reveal That Enslaved Africans Recognized Substantial Parts of the New World Flora. Proceedings of the National Academy of Sciences of the United States of America 111(50):E5346-5353.

5. Andel T, Maas P, Dobreff J (2012a) Ethnobotanical Notes from Daniel Rolander's Diarium Surinamicum (1754-1756): Are These Plants Still Used in Suriname Today? Taxon 61(4):852-863.

6. Andel T, Veldman S, Maas P, Thijsse G, Eurlings, M (2012b) The Forgotten Hermann Herbarium: A 17th Century Collection of Useful Plants from Suriname Taxon 61(6):1296-1304.

7. Brandão MGL, Zanetti NNS, Oliveira $P$, Grael CFF, Santos $A C P$, Monte-Mór RLM (2008) Brazilian Medicinal Plants Described by 19th Century European Naturalists and in the Official Pharmacopoeia. Journal of Ethnopharmacology 120(2):141-148.
8. Brandão MGL, Pignal M, Romaniuc S, Grael CFF, Fagg CW (2012) Useful Brazilian Plants Listed in the Field Books of the French Naturalist Auguste de Saint-Hilaire (1779-1853). Journal of Ethnopharmacology 143(2):488-500.

9. Breitbach UB, Niehues M, Lopes NP, Faria JEQ, Brandão MGL (2013) Amazonian Brazilian Medicinal Plants Described by C.F.P. von Martius in the 19th Century. Journal of Ethnopharmacology 147(1):180-189.

10. Buenz EJ, Schnepple DJ, Bauer BA, Elkin PL, Riddle JM, Motley TJ (2004).Techniques: Bioprospecting Historical Herbal Texts by Hunting for New Leads in Old Tomes Trends in Pharmacological Sciences 25(9):494-498.

11. Conservatory and Botanical Garden of Geneva. [http://www. ville-ge.ch/musinfo/bd/cjb/auxilium/search.php] Accessed 21 November 2013

12. Cosenza G, Somavilla NS, Fagg, CW, Brandão MGL (2013) Bitter Plants Used as Substitute of Cinchona Spp. (quina) in Brazilian Traditional Medicine. Journal of Ethnopharmacology 149(3):790796.

13. Cero M, Saller R, Weckerle CS (2014) The Use of the Local Flora in Switzerland: A Comparison of Past and Recent Medicinal Plant Knowledge. Journal of Ethnopharmacology 151(1):253-264.

14. Duan S, Liu Z, Feng X, Zheng K, Cheng L, Zheng X. (2012) Diversity and characterization of ramie-degumming strains. Scientia Agricola 69(2): 119-125.

15. Fagg CW, Nic E, Milliken W, Hind DJN, Brandão MGL (2015) Useful Brazilian Plants Listed in the Manuscripts and Publications of the Scottish Medic and Naturalist George Gardner (1812 - 1849). Journal of Ethnopharmacology 161:18-29.

16. Filgueiras TS, Peixoto, AL (2002) Flora e Vegetação do Brasil na Carta de Caminha. Acta Botanica Brasilica 16(3):263-72.

17. Gaglioti $A L$, Romaniuc-Neto S (2014) Urticaceae no Estado de São Paulo, Brasil. Diversidade e Conservação das urtigas de São Paulo. 1 ed. Saarbrücken: OmniScriptum GmbH \& Co. KG, São Paulo, SP, Brazil

18. Giorgetti M, Rossi L, Rodrigues E (2011) Brazilian Plants with Possible Action on the Central Nervous System: A Study of Historical Sources from the 16th to 19th Century. Revista Brasileira de Farmacognosia 109(2):338-347.

19. Guerra GAD, Angelo-Menezes MN, Ming LC (2011). Hermenêutica Botânica e Antropização na Amazônia: Exsicatas de Verbenáceas da Amazônia Legal no Herbário do New York Botanical Garden. Novos Cadernos NAEA 14(2):237-264.

20. Hamedi A, Zarshenas MM, Sohrabpour M, Zargaran A (2013) A Herbal medicinal oils in traditional Persian medicine. Pharmaceutical Biology 51(9):1208-1218.

21. Kerr EW, Clement RC (1980) Práticas Agrícolas e Consequências Genéticas que Possibilitaram aos Índios da Amazônia uma Melhor Adaptação às Condições Ecológicas da Região. Acta Amazonica 10(2):251-261.

22. Kufer J, Förther H, Pöll E, Heinrich M (2005) Historical and Modern Medicinal Plant Uses the Example of the Ch'orti' Maya and Ladinos in Eastern Guatemala The Journal of Pharmacy and Pharmacology 57(9):1127-1152.

23. Kury LB. (2011) Entre Utopia e Pragmatismo: a História Natural no Iluminismo tardio. In: Soares LC (Coord.) Da revolução científica à big (business) science. 1 ed. HUCITEC, São Paulo,105-153.

24. Kury LB (2001) Viajantes Naturalistas no Brasil Oitocentista: Experiência, Relato e Imagem. História, Ciências, SaúdeManguinhos 5(8): 863-880. 
25. Kury LB (1998) Les Instructions de Voyage dans les Expeditions Scientifiques Françaises. Revue d'Histoire des Science 51(1): 65-91.

26. Leite MLM (1995) Naturalistas Viajantes. História, Ciências, Saúde - Manguinhos 1(2): 7-19.

27. Leonti M. (2011) The Future is Written: Impact of Scripts on the Cognition, Selection, Knowledge and Transmission of Medicinal Plant Use and Its Implications for Ethnobotany and Ethnopharmacology. Journal of Ethnopharmacology 134(3):542555 .

28. Lopes MM, Heizer A (Coord.) (2011) Colecionismos, Prática de Campo e Representações. 1ed., EDUEPB, Campina Grande, PB, Brazil

29. Luczaj $L$ (2010) Changes in the Utilization of Wild Green Vegetables in Poland since the 19th Century: A Comparison of Four Ethnobotanical Surveys. Journal of Ethnopharmacology doi: 10.1016/j.jep.2010.01.038

30. Luczaj $L$, Köhler P, Piroz̀nikow E, Graniszewska M, Pieroni $A$, Gervasi T. (2013) Wild Edible Plants of Belarus : From Rostafínski ' S Questionnaire of $\mathbf{1 8 8 3}$ to the Present. Journal of Ethnobiology and Ethnomedicine 9:1-21.

31. Medeiros MFT, Albuquerque UP (2014) Food Flora in 17th Century Northeast Region of Brazil in Historia Naturalis Brasiliae. Journal of Ethnobiology and Ethnomedicine 10:50.

32. Moraes PLR, Dobreff J, Reinhammar LG (2014) The Plants by Daniel Rolander (1723-1793) in Diarium Surinamicum (17541765) and Herbaria. Phytotaxa 165(1):1.

33. Natale A, Pollio A (2012) A Forgotten Collection: The Libyan Ethnobotanical Exhibits (1912-14) by A. Trotter at the Museum 0. Comes at the University Federico II in Naples, Italy. Journal of Ethnobiology and Ethnomedicine 8:4.

34. Pataca EM (2011) Coletar, Preparar, Remeter, Transportar Práticas de História Natural nas Viagens Filosóficas Portuguesas (1777-1808). Revista Brasileira de História da Ciência 4(2):125-138

35. Pataca EM, Pinheiro $R$ (2005) Instruções de viagem para a investigação científica do território brasileiro. Revista Brasileira de História da Ciência 3(1): 58-79.

36. Peckolt T, Peckolt G (1888) Historia das Plantas Medicinaes e Úteis do Brazil. Laemmert \& C, Rio de Janeiro, RJ, Brazil

37. Reyes-García V, Luz AC, Gueze M, Paneque-Gálvez J, Macía, MJ, Orta-Martínez M, Pino J (2013) Secular Trends on Traditional Ecological Knowledge: An Analysis of Changes in Different Domains of Knowledge among Tsimane' Men. Learning and Individual Differences 27:206-212.

38. Sandberg F, Perera-Ivarsson P, Rushdey, H.ES (2005) A Swedish Collection of Medicinal Plants from Cameroon. Journal of Ethnopharmacology 102(3):336-343.

39. Spalik, K. (2014) Pre-Linnaean Herbaria Viva of Helwing in the Collections of the National Library of Poland and the University of Warsaw. Acta Societatis Botanicorum Poloniae 83(1):13-16.

40. Saint-Hilaire A (1975) Viagem pelas províncias do Rio de Janeiro e Minas Gerais (1779-1853). EDUSP, Sao Paulo, SP, Brazil

41. Saint-Hilaire A (2011) História das plantas mais notáveis do Brasil e do Paraguai: Compreendendo sua descrição e dissertações sobre suas relações, seus usos, etc. Ed. Fino Trato, Belo Horizonte, MG, Brazil

42. Sorarú SB (1972) Revision de las Urticaceae argentinas. Darwinina 17: 246-325.
43. Spruce, R (2006) Notas de um botânico na Amazônia. 1.ed., Itatiaia, Rio de Janeiro, RJ, Brazil

44. Wu ZY, Monro AK, Milne RI, Wang H, Yi TS, Liu J, Li DZ (2013) Molecular phylogeny of the nettle family (Urticaceae) inferred from multiple loci of three genomes and extensive generic sampling. Molecular Phylogenetics Evolution 69(3):814-827.

45. Vos PS (2010) European Materia Medica in Historical Texts: Longevity of a Tradition and Implications for Future Use. Journal of Ethnopharmacology 132(1):28-47.

46. Vos, PS (2007) Natural History and the Pursuit of Empire in Eighteenth-Century Spain. Eighteenth-Century Studies 40(2):209-3

Received: 30 January 2015

Accepted: 01 May 2015

Published: 12 June 2015 